\title{
Direct Organocatalytic Asymmetric $\alpha$-Chlorination of Aldehydes
}

Nis Halland, Alan Braunton, Stephan Bachmann, Mauro Marigo and Karl Anker Jørgensen*

Danish National Research Foundation: Center for Catalysis, Department of Chemistry

Aarhus University, DK-8000 Aarhus C, Denmark

kaj@chem.au.dk

\section{Supporting Information}

General. The ${ }^{1} \mathrm{H}$ NMR and ${ }^{13} \mathrm{C}$ NMR spectra were recorded at $400 \mathrm{MHz}$ and $100 \mathrm{MHz}$, respectively. The chemical shifts are reported in ppm relative to $\mathrm{CHCl}_{3}(\delta=7.26)$ for ${ }^{1} \mathrm{H} \mathrm{NMR}$ and relative to the central $\mathrm{CDCl}_{3}$ resonance $(\delta=77.0)$ for ${ }^{13} \mathrm{C}$ NMR. Flash chromatography (FC) was carried out using Merck silica gel 60 (230-400 mesh). Optical rotation was measured on a PerkinElmer 241 polarimeter. NMR data of known compounds is in agreement with literature values.

Materials. The commercially available aldehydes and organocatalysts were used without further purifications. Substrate $\mathbf{1} \mathbf{h}^{1}$ and the catalysts $\mathbf{3} \mathbf{d},{ }^{2} \mathbf{3} \mathbf{h},{ }^{3} \mathbf{3 i}^{4}$ and $\mathbf{3} \mathbf{j}^{5}$ were synthesized according to literature procedures. All solvents were of p. a. quality and used without further purification. The commercially available NCS was recrystallized from AcOH before use.

General procedure for the organocatalytic $\alpha$-chlorination of aldehydes. The catalyst $(0.05$ mmol, $10 \mathrm{~mol} \%)$ was added to a stirred ice-cooled $\left(0{ }^{\circ} \mathrm{C}\right)$ solution of the aldehyde $(0.5 \mathrm{mmol})$ in $\mathrm{CH}_{2} \mathrm{Cl}_{2}(1.0 \mathrm{~mL})$ followed by the addition of $\mathrm{NCS}(87 \mathrm{mg}, 0.65 \mathrm{mmol}, 1.3 \mathrm{eq}$.). The reaction mixture was after $1 \mathrm{~h}$ allowed to warm to ambient temperature and stirred until the aldehyde was completely consumed as determined by ${ }^{1} \mathrm{H}$ NMR spectroscopy of the reaction mixture and confirmed by GC analysis. Pentane was added to the reaction mixture and the precipitated NCS, succinimide and the catalyst were filtered off. After removal of the solvents the pure products could be extracted into pentane and isolated.

2-chloro-3-methyl butanal 2a: The ee was determined by $\mathrm{GC}$ on a Chrompak CP-
Chirasil Dex CB-column. Temperature program: $70{ }^{\circ} \mathrm{C}$ isotherm for 9 min. $\mathrm{R}_{\mathrm{t}}(\mathrm{min})$ :
$6.7((R)$-enantiomer); $7.0((S)$-enantiomer $)$. The absolute configuration was determined by optical rotation and compared with literature values. ${ }^{6}$ 


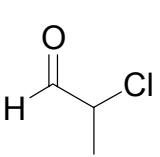

2-chloro propanal $\mathbf{2 b}$ : The title compound was isolated as the corresponding methyl ester by the following procedure: The reaction mixture was diluted with $3.0 \mathrm{~mL} \mathrm{t}$ $\mathrm{BuOH}$ and $3.0 \mathrm{~mL} 1 \mathrm{M} \mathrm{NaH} \mathrm{PO}_{4}$ (aq.) and $3.0 \mathrm{~mL} 1 \mathrm{M} \mathrm{KMnO}_{4}$ (aq.) were added successively. After $1 \mathrm{~min}$ of vigorous stirring $3.0 \mathrm{~mL}$ sat. $\mathrm{NaHSO}_{3}$ (aq.) was added and the $\mathrm{pH}$ was adjusted to approximately 3 with $1 \mathrm{M} \mathrm{HCl}$ at $0{ }^{\circ} \mathrm{C}$. The resulting mixture was extracted with EtOAc, washed with water and brine, and dried over $\mathrm{Na}_{2} \mathrm{SO}_{4}$. The organic layer was concentrated and the residual acid was dissolved in toluene $(2.0 \mathrm{~mL})$ and $\mathrm{MeOH}(5.0 \mathrm{~mL})$, and $\mathrm{TMSCHN}_{2}(2.0 \mathrm{M}$ in hexane) was added drop-wise until the yellow color persisted. The solution was stirred for an additional $5 \mathrm{~min}$ and quenched with a drop of $\mathrm{AcOH}$. The solvents were removed and the crude product was purified by $\mathrm{FC}$ using pentane/ $\mathrm{Et}_{2} \mathrm{O}(9: 1)$ to afford the pure product. The ee was determined by GC on a Chrompak CP-Chirasil Dex CB-column. Temperature program: $70{ }^{\circ} \mathrm{C}$ isotherm for $9 \mathrm{~min} . \mathrm{R}_{\mathrm{t}}(\mathrm{min})$ : $3.7((R)$-enantiomer); $4.0((S)$-enantiomer $)$. The title compound $\mathbf{2 b}$ was reduced to the corresponding alcohol by the analogous procedure described for $\mathbf{2 d}$ (see below). The absolute configuration of the chloro alcohol was determined by optical rotation and compared with literature values. ${ }^{6}$
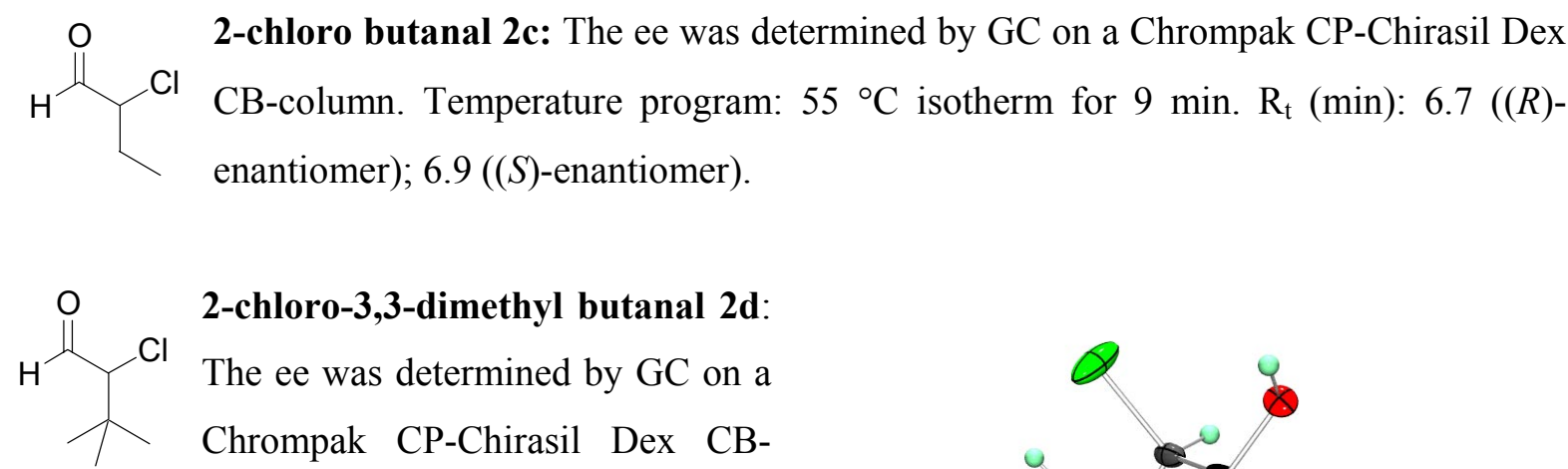
column. Temperature program: $65{ }^{\circ} \mathrm{C}$ isotherm for $10 \min . \mathrm{R}_{\mathrm{t}}(\min )$ : $4.9((R)$-enantiomer); 5.1 $((S)$-enantiomer). The absolute configuration was determined by an X-ray structure of a single crystal of $4 \mathbf{b},{ }^{7}$ which was obtained by the following procedure: The reaction mixture was diluted with $\mathrm{MeOH}(2.0 \mathrm{~mL})$ and $\mathrm{NaBH}_{4}(100$ $\mathrm{mg}, 2.6 \mathrm{mmol})$ was added in several portions.

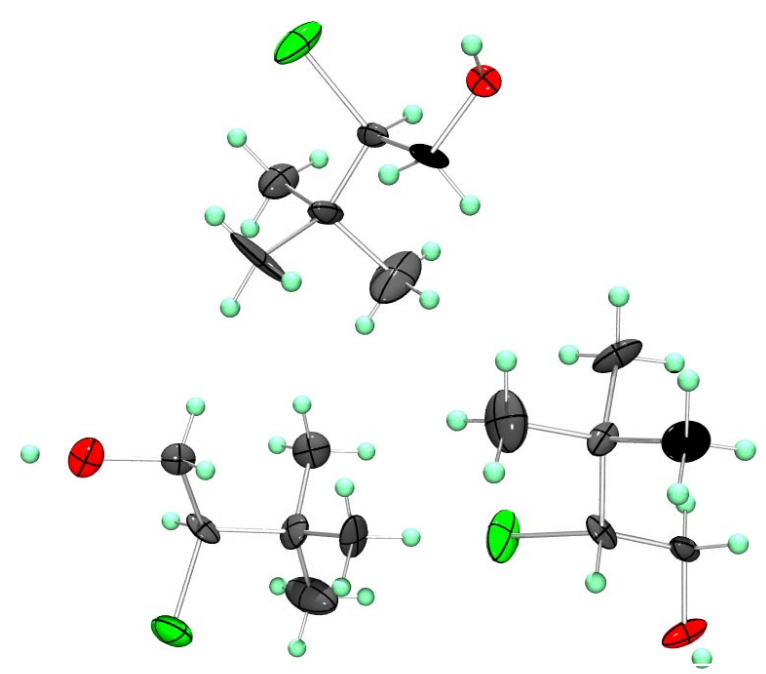

Figure S1. X-ray structure of compound $4 \mathrm{~b}$ 
The mixture was then stirred for 10 min, quenched with $\mathrm{H}_{2} \mathrm{O}$ and extracted with EtOAc. The organic layer was separated, dried over $\mathrm{Na}_{2} \mathrm{SO}_{4}$ and the solvent was removed. The crude product was purified by $\mathrm{FC}$ over silica with $\mathrm{CH}_{2} \mathrm{Cl}_{2} / \mathrm{Et}_{2} \mathrm{O}(9: 1)$.

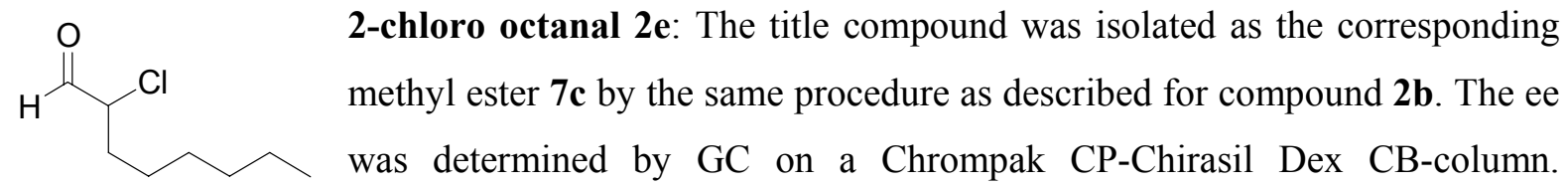
Temperature program: From $70{ }^{\circ} \mathrm{C}$ to $200{ }^{\circ} \mathrm{C}$ at a rate of $10{ }^{\circ} \mathrm{C} / \mathrm{min} . \mathrm{R}_{\mathrm{t}}(\mathrm{min}): 8.1$ (enantiomer-1); 8.2 (enantiomer-2). Alternatively the title compound can be isolated as the corresponding epoxide 5 by the following procedure: ${ }^{6}$ The reaction mixture was diluted with $\mathrm{MeOH}(2.0 \mathrm{~mL})$ and $\mathrm{NaBH}_{4}$ (100 mg, $2.6 \mathrm{mmol}$ ) was added in several portions. The mixture was then stirred for $10 \mathrm{~min}$, quenched with $\mathrm{H}_{2} \mathrm{O}$ and extracted with EtOAc. The organic layer was separated, dried over $\mathrm{Na}_{2} \mathrm{SO}_{4}$ and the solvent was removed. The crude product was purified by $\mathrm{FC}$ over silica with $\mathrm{CH}_{2} \mathrm{Cl}_{2} / \mathrm{Et}_{2} \mathrm{O}$ (9:1). The 2-chloro octanol $\mathbf{4 c}$ was then distilled over $\mathrm{KOH}$ (2 eq.) in order to isolate the pure 1,2epoxy octane 5. The ee of the epoxide was determined by GC on a Chrompak CP-Chirasil Dex CBcolumn. Temperature program: $75{ }^{\circ} \mathrm{C}$ isotherm for $16 \mathrm{~min} . \mathrm{R}_{\mathrm{t}}(\mathrm{min}): 15.4((S)$-enantiomer); 15.7 $((R)$-enantiomer). The absolute configuration was determined by measurement of the optical rotation of the epoxide $\mathbf{5}$ and comparison with literature values. ${ }^{8}$

2-chloro pentenal 2f: ${ }^{1} \mathrm{H}$ NMR $\delta 9.51(\mathrm{~d}, 1 \mathrm{H}, J=2.4 \mathrm{~Hz}, \mathrm{C}(H) \mathrm{O}), 5.82(m, 1 \mathrm{H}$,
$\left.\mathrm{CH}_{2} \mathrm{CH}-\right), 5.19\left(\mathrm{~m}, 2 \mathrm{H},-\mathrm{CH}_{2}\right), 4.22(\mathrm{ddd}, 1 \mathrm{H}, J=2.4,6.0$ and $8.0 \mathrm{~Hz}, \mathrm{CH}-\mathrm{Cl}), 2.77$
$\left(\mathrm{~m}, 1 \mathrm{H}, \mathrm{CH}_{2} \mathrm{CHCH}_{2}\right), 2.59\left(\mathrm{~m}, 1 \mathrm{H}, \mathrm{CH}_{2} \mathrm{CHCH}_{2}\right){ }^{13} \mathrm{C} \mathrm{NMR} \delta 195.0,131.8,119.8$, column. Temperature program: $65{ }^{\circ} \mathrm{C}$ isotherm for $10 \mathrm{~min} . \mathrm{R}_{\mathrm{t}}(\mathrm{min}): 9.0$ (enantiomer-1); 9.2 (enantiomer-2).

2-chloro-3-phenyl propanal 2g: The title compound was isolated as the
corresponding alcohol $\mathbf{4 a}$ as described for $\mathbf{2 d}$. The ee was determined by HPLC on a
$\mathrm{Ph}$ Daicel Chiralpak AS column with hexane/i-PrOH $(97: 3)$ as the eluent. $\mathrm{R}_{\mathrm{t}}(\mathrm{min}): 7.9$ (enantiomer-1); 9.3 (enantiomer-2). 


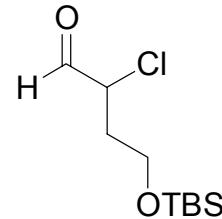

2-chloro-4-(tert-butyldimethylsilyloxy)-butanal $\mathbf{2 h}$ : The title compound was isolated as the corresponding methyl ester $\mathbf{7 d}$ by the same procedure as described for compound $\mathbf{2 b}$. ${ }^{1} \mathrm{H}$ NMR $\delta 4.49(\mathrm{dd}, 1 \mathrm{H}, J=4.8$ and $8.8 \mathrm{~Hz}, \mathrm{C}(H)-\mathrm{Cl}), 3.75$ (s, $\left.3 \mathrm{H}, \mathrm{OCH}_{3}\right), 3.73\left(\mathrm{~m}, 2 \mathrm{H}, \mathrm{OCH}_{2}\right), 2.22\left(\mathrm{~m}, 1 \mathrm{H}, \mathrm{CH}_{2}\right), 2.00\left(\mathrm{~m}, 1 \mathrm{H}, \mathrm{CH}_{2}\right), 0.85(\mathrm{~s}$, $\left.9 \mathrm{H},\left(\mathrm{CH}_{3}\right)_{3}\right), 0.02\left(\mathrm{~d}, 6 \mathrm{H}, J=6.6 \mathrm{~Hz}, \mathrm{Si}\left(\mathrm{CH}_{3}\right)_{2}\right) .{ }^{13} \mathrm{C} \mathrm{NMR} \delta 170.4,58.7,54.1,52.9,37.5,25.8,-5.5$. The ee of 7d was determined by GC on a Chrompak CP-Chirasil Dex CB-column. Temperature program: From $70{ }^{\circ} \mathrm{C}$ to $120{ }^{\circ} \mathrm{C}$ at a rate of $10{ }^{\circ} \mathrm{C} / \mathrm{min}$, then isotherm for $20 \mathrm{~min}$ at $120{ }^{\circ} \mathrm{C}$. $\mathrm{R}_{\mathrm{t}}$ (min): 20.6 (enantiomer-1); 21.3 (enantiomer-2).

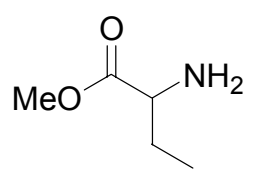

2-amino butyric acid methyl ester 9: Compound 9 was prepared according to Scheme 1. The chloro ester 7a was synthesized in analogy to the procedure described for $\mathbf{2 b}$ (see above). The ee of $\mathbf{7 a}$ was determined by GC on a Chrompak CP-Chirasil Dex CB-column. Temperature program: From $70{ }^{\circ} \mathrm{C}$ to $90{ }^{\circ} \mathrm{C}$ at a rate of $10{ }^{\circ} \mathrm{C} / \mathrm{min}$, then isotherm for $10 \mathrm{~min}$ at $90^{\circ} \mathrm{C} . \mathrm{R}_{\mathrm{t}}(\mathrm{min}): 7.7((R)$-enantiomer); $7.9((S)$-enantiomer). The chloro ester 7a (100 mg, $0.73 \mathrm{mmol})$ was dissolved in DMF $(10 \mathrm{~mL})$ and $\mathrm{NaN}_{3}(300 \mathrm{mg}, 4.6 \mathrm{mmol}, 6.3$ eq.) was added. The reaction mixture was heated at $60^{\circ} \mathrm{C}$ overnight, cooled to ambient temperature, quenched with $\mathrm{H}_{2} \mathrm{O}$ and extracted with $\mathrm{Et}_{2} \mathrm{O}$. The organic layer was washed with $\mathrm{H}_{2} \mathrm{O}(3 \times 40 \mathrm{~mL})$ and dried over $\mathrm{Na}_{2} \mathrm{SO}_{4}$. After removal of the solvent compound 8 was isolated. ${ }^{1} \mathrm{H}$ NMR $\delta 3.72$ (s, $4 \mathrm{H}, \mathrm{CH}-\mathrm{N}_{3}$ and $\left.\mathrm{OCH}_{3}\right), 1.82\left(\mathrm{~m}, 1 \mathrm{H}, \mathrm{CH}_{2}\right), 1.75\left(\mathrm{~m}, 1 \mathrm{H}, \mathrm{CH}_{2}\right), 0.95\left(\mathrm{t}, 3 \mathrm{H}, J=7.2 \mathrm{~Hz}, \mathrm{CH}_{3}\right) .{ }^{13} \mathrm{C}$ NMR: $\delta 171.0,63.3,52.6,24.9,10.2$. The ee of $\mathbf{8}$ was determined by GC on a Chrompak CPChirasil Dex CB-column. Temperature program: From $70{ }^{\circ} \mathrm{C}$ to $85^{\circ} \mathrm{C}$ at a rate of $10{ }^{\circ} \mathrm{C} / \mathrm{min}$, then isotherm for $10 \mathrm{~min}$ at $85^{\circ} \mathrm{C} . \mathrm{R}_{\mathrm{t}}(\mathrm{min})$ : $8.7((S)$-enantiomer); $9.4((R)$-enantiomer). Compound 9 was obtained by reduction of 8 with $\mathrm{Pd} / \mathrm{C}$ in $\mathrm{MeOH}$ with $\mathrm{H}_{2}$ (1 atm) overnight in a $40 \%$ yield from butanal 1c.

$\mathrm{OH}$ 2-amino butanol 11: The title compound was synthesized in analogy to compound 9 $\mathrm{NH}_{2}$ starting from 2-chloro butanol 4d. The substitution reaction from $\mathbf{4 d}$ to $\mathbf{1 0}$ was conducted at $90{ }^{\circ} \mathrm{C}$ for $24 \mathrm{~h} .{ }^{1} \mathrm{H}$ NMR: $\delta 3.71\left(\mathrm{dd}, 1 \mathrm{H}, J=3.6\right.$ and $\left.11.2 \mathrm{~Hz}, \mathrm{CH}_{2}\right), 3.56$ (dd, $1 \mathrm{H}, J=7.6$ and $\left.11.2 \mathrm{~Hz}, \mathrm{CH}_{2}\right), 3.41\left(\mathrm{~m}, 1 \mathrm{H}, \mathrm{CH}-\mathrm{N}_{3}\right), 1.77$ (br s, $\left.1 \mathrm{H}, \mathrm{OH}\right), 1.57\left(\mathrm{~m}, 2 \mathrm{H}, \mathrm{CH}_{2}\right.$ ), $1.02\left(\mathrm{t}, 3 \mathrm{H}, J=7.6 \mathrm{~Hz}, \mathrm{CH}_{3}\right) .{ }^{13} \mathrm{C} \mathrm{NMR}: \delta 65.9,64.9,23.7,10.5$. The ee was maintained during this transformation as confirmed by GC analysis. The ee of the $\mathbf{1 0}$ was determined by $\mathrm{GC}$ on a 
Chrompak CP-Chirasil Dex CB-column. Temperature program: From $70{ }^{\circ} \mathrm{C}$ to to $90^{\circ} \mathrm{C}$ at a rate of $10^{\circ} \mathrm{C} / \mathrm{min}$, then isotherm at $90^{\circ} \mathrm{C} . \mathrm{R}_{\mathrm{t}}(\mathrm{min}): 21.2((R)$-enantiomer); $21.4((S)$-enantiomer). The title compound was obtained by reduction of $\mathbf{1 0}$ with $\mathrm{Pd} / \mathrm{C}$ in $\mathrm{MeOH}$ with $\mathrm{H}_{2}(1 \mathrm{~atm})$ for $5 \mathrm{~h}$. The absolute configuration was determined by comparison with a commercially available sample of the title compound.

\section{References}

1. Stoller, A.; Mioskowski, C.; Sepulchre, C.; Bellamy, F. Tetrahedron Lett. 1991, 32, 495.

2. This catalyst was synthesized following a peptide coupling method giving the known compound 3d: Hill, R. R.; Birch, D.; Jeffs, G. E.; North, M. Org. Biomol. Chem. 2003, 1, 965.

3. Mathre, D.; Jones, T. K.; Lyndon, C. X.; Blacklock, T. J.; Reamer, R. A., Mohan, J. J.; Turner Jones, E. T.; Hoogsteen, K.; Baum, M. W.; Grabowski, E. J. J. J. Org. Chem. 1991, 56,751 .

4. Chong, J. M.; Clarke, I. S.; Koch, I.; Olbach, P. C.; Taylor, N. J. Tetrahedron: Asymmetry 1995, 6, 409 .

5. Nakajima, M.; Tomioka, K.; Koga, K. Tetrahedron 1993, 49, 9735.

6. Koppenhoefer, B.; Weber, R.; Schurig, V. Synthesis 1982, 316.

7. X-Ray work: Crystals of $\mathbf{4 b}, \mathrm{C}_{6} \mathrm{H}_{13} \mathrm{ClO}$, are hexagonal, $\mathrm{P}_{2}$, with unit cell: $\mathrm{a}=17.826(2) \AA$, $\mathrm{c}$ $=6.193(2) \AA, \mathrm{V}=1704.3(6) \AA^{3}, \mathrm{Z}=4$. Data were collected at $100 \mathrm{~K}$ on a SMART diffractometer with $\mathrm{CCD}$ detector. The structure solved by direct methods and refined by least squares methods to final $\mathrm{R}=0.103, \mathrm{R}_{\mathrm{w}}=0.128, \mathrm{GOF}=1.99$ using 3737 reflections with $\mathrm{I}>3 \sigma(\mathrm{I}), 214$ parameters refined The crystals are of low quality as their melting point is close to room temperature. Some disorder of the t-Bu groups is obviously frozen in at $100 \mathrm{~K}$ as is seen from large residual density between the carbon atoms of these groups, and from the unreasonable displacement parameters. Least squares refinement included a parameter according to Rogers (1981) refined against all 37737 significant reflections including 1595 Bijvoet pairs. The indication from this - although weak - supports the chirality found in other ways.

8. Paden-Jones, G. C.; McErlean, C. S. P.; Hayes, P.; Moore, C. J.; Konig, W. A.; Kitching, W. J. Org. Chem. 2001, 66, 7487. 